\title{
Pilgrims of Love: The Anthropology of a Global Sufi Cult
}

Pnina Werbner

London: Hurst \& Co., 2003. 348 pages.

Pnina Werbner's Pilgrims of Love, a truly exceptional book in several important ways, is the result of some eleven years of fieldwork in Britain and Pakistan. While the topic, understanding a transnational Sufi cult, is quite conventional within the discipline of anthropology, the time span in which the research was conceived and conducted is perhaps one wherein anthropology 
began to question seriously even its most taken-for-granted truths. This makes the final product anything but conventional.

The author makes very clear her position as an anthropologist and the difficulties she experienced as a western Jewish female academic writing about a Pakistani, or second-generation Pakistani, predominantly Muslim male practitioner's perspective. Her honesty about the nature of her field experience, the classic nature of the research itself within the canon of anthropological literature, and her assessment of what she calls "the limits of postmodern anthropology" (pp. 14-15, 291-302) add a certain depth of substance to the discipline's ongoing discussion of the subject-object relationship. This text is an important contribution to the body of literature within the anthropology of religion and Islam, comparative studies of Islamic movements, transnationalism, and, in general, to students and scholars of Pakistan and South Asia.

This work focuses on the life of a living saint, Zindapir, and his lodge in Pakistan, Ghamkol Sharif, and how globalization and postcolonial conditions have influenced the spread of his influence in Pakistan and Britain. Whereas most similar studies are either about a living or a legendary saint, this text is both; in that sense, it is quite unique. One of the book's more surprising aspects is that it takes on a very contemporary topic with a very classical theoretical approach. While Werbner does seek to dialogue with such scholars as Edward Said and Michel Foucault, her project is more closely aligned with the classical theoretical approaches of Max Weber, Claude Levi-Strauss, and Victor Turner. One wonders how the text might have developed differently if Werbner had chosen to situate her work squarely within the current literature on globalization and transnationalism. Nevertheless, the text is interesting from the point of view that she demonstrates how classical anthropological theory can evoke salient themes even in today's globalized world.

One of the book's more intriguing themes is the socially cooperative efforts that go into the making of sacred space. Werbner approaches this by describing the general landscape of the lodge in Pakistan, as well as the mosque and community-building activities in Britain, in terms of a group inserting itself into a larger foreign and mostly non-Muslim public space. The book's central section focuses specifically on the various public celebrations that occur in both countries. While the commentary on these celebrations in Pakistan evokes familiar themes about the events' function as a large-scale redistribution of resources and the saint's miraculous role in feeding the poor, these events take on a significantly different meaning in Britain, where a Muslim minority population organizes public processions. 
Werbner explains how her informants viewed "western" public space and what motivated them to organize public processions. She comments that the areas of the non-Muslim world, in this case Britain, where no established branches of Zindapir's order had been set up, were seen as blank spaces on a map. Public processions then served to inscribe not only the identity of Pakistani migrants into the British landscape, but also to inscribe the saint's influence into a new sphere where adherents might attract new followers. New centers served as sites where Zindapir's khulafa' ("emissaries of the saint beyond the central lodge," p. 157) emulated both him and his lodge in Pakistan (pp. 157-82).

Werbner describes sacred spaces in the minutest detail, down to how Zindapir himself carefully constructed spaces for interacting appropriately with visitors, how the lodge was continually built and rebuilt through volunteer labor, and how the saint's cave was opened and framed in a narrative about him as a living saint after his physical death. More than simply describing these spaces, Werbner analyzes how people interact with the saint through space. For example, she includes interesting excerpts from her fieldwork on the building of his gravesite and relates various individuals' attestation that the saint's power has increased exponentially by virtue of him being outside, out of his contemplative cave, and available at any time for any person.

Further, she describes how Zindapir's tomb is decorated with flowers and different chaddars (a "very large scarf, usually white, that covers the head and upper part of the body; sheet") from various regions and different groups of people as they arrive at his tomb in waves. Thus, his tomb can be read in terms of its constant transformation, thereby representing the many roles he filled while serving his many adherents.

The book also takes up the subject of knowledge, who is deemed to have it, and how it was acquired. This point comes to a head in the final chapter, when Werbner describes the various expectations she encountered when telling people that her research would lead to a "book." She met with a positive response from Zindapir's followers in Britain; however, the saint himself, influenced by others near him in Pakistan, ordered that an explanatory English-language pamphlet she had helped write about the order be burned. This experience was halting, but finally opened a productive field of inquiry into the validity of anthropological knowledge and writing, as well as knowledge as it is understood in other contexts.

This fascinating conclusion, far from being conclusive in any respect, might actually have been framed more productively as a starting point for the book, rather than added at the end in a sort of confessional manner. This single section is enough to make the entire book worthwhile reading for any- 
one interested in how knowledge is constructed and how current anthropological work deals with dialogism and reflexivity.

Mieke Maria Curtis ABD, Anthropology

University of Texas at Austin, Texas 